\title{
Quantitative PCR detection of Batrachochytrium dendrobatidis DNA from sediments and water
}

\author{
Julie D. Kirshtein ${ }^{1}$, Chauncey W. Anderson ${ }^{2, *}$, John S. Wood ${ }^{3}$, Joyce E. Longcore ${ }^{4}$, \\ Mary A. Voytek ${ }^{1}$
}

\author{
${ }^{1}$ US Geological Survey, MS 430, 12201 Sunrise Valley Dr., Reston, Virginia 20192, USA \\ ${ }^{2}$ US Geological Survey, Oregon Water Science Center, 2130 SW Fifth Avenue, Portland, Oregon 97201, USA \\ ${ }^{3}$ Pisces Molecular, 2200 Central Avenue, Suite F, Boulder, Colorado 80301, USA \\ ${ }^{4}$ University of Maine, Department of Biological Sciences, 5722 Deering Hall, Orono, Maine 04469, USA
}

\begin{abstract}
The fungal pathogen Batrachochytrium dendrobatidis (Bd) causes chytridiomycosis, a disease implicated in amphibian declines on 5 continents. Polymerase chain reaction (PCR) primer sets exist with which amphibians can be tested for this disease, and advances in sampling techniques allow non-invasive testing of animals. We developed filtering and PCR based quantitative methods by modifying existing PCR assays to detect Bd DNA in water and sediments, without the need for testing amphibians; we tested the methods at 4 field sites. The SYBR based assay using Boyle primers (SYBR/Boyle assay) and the Taqman based assay using Wood primers performed similarly with samples generated in the laboratory (Bd spiked filters), but the SYBR/Boyle assay detected Bd DNA in more field samples. We detected Bd DNA in water from 3 of 4 sites tested, including one pond historically negative for chytridiomycosis. Zoospore equivalents in sampled water ranged from 19 to $454 \mathrm{l}^{-1}$ (nominal detection limit is 10 DNA copies, or about 0.06 zoospore). We did not detect DNA of Bd from sediments collected at any sites. Our filtering and amplification methods provide a new tool to investigate critical aspects of $\mathrm{Bd}$ in the environment.
\end{abstract}

KEY WORDS: Amphibian $\cdot$ Chytridiomycosis $\cdot$ Detection $\cdot$ Disease $\cdot$ Filter $\cdot$ PCR $\cdot$ Primers $\cdot$ Water Resale or republication not permitted without written consent of the publisher

\section{INTRODUCTION}

Diseases are contributing to declines in amphibian populations worldwide (Crawshaw 2000). One disease agent that is receiving considerable attention is the pathogenic chytrid Batrachochytrium dendrobatidis (Bd), which causes chytridiomycosis (Berger et al. 1998, Daszak et al. 1999, Longcore et al. 1999). Recent advances in sampling techniques using polymerase chain reaction (PCR) have enhanced the ability to document the spread of Bd without using invasive testing of animals (Kriger et al. 2006, Hyatt et al. 2007). Many gaps exist, however, in our knowledge of this microscopic fungus when it is outside of its hosts. The need for an amphibian habitat testing technique has been identified repeatedly (Boyle et al. 2004, Australian Government Department of Environment and Heritage 2006).
We developed a quantitative method to detect $\mathrm{Bd}$ DNA in water and sediment and field tested it at sites with positive and negative histories of chytridiomycosis. The method is based on traditional filtering techniques for field sampling, followed by standard microbiological laboratory techniques and quantitative PCR assays (Annis et al. 2004, Boyle et al. 2004, J. S. Wood unpubl.).

\section{MATERIALS AND METHODS}

Batrachochytrium dendrobatidis cultures. To evaluate Bd DNA recovery from filters we spiked test liquids with zoospores harvested from culture. We grew the type strain of $B$. dendrobatidis (JEL 197) on nutrient agar and after 3 to $5 \mathrm{~d}$ we harvested zoospores into sterile deionized water, and kept the zoospore suspen- 
sion on ice overnight until use. Zoospore concentrations were determined microscopically.

Evaluation of Bd zoospore recovery by filtration. Triplicate samples were prepared by adding a known number of zoospores into either sterile water, phosphate buffered saline (PBS), or pond water (e.g. $1.3 \times$ $10^{8}$ zoospores in 21 of fluid), and then pumping through a Sterivex GP $0.2 \mu \mathrm{m}$ filter (Millipore). After filtering, we drained and froze filters until DNA extraction.

DNA extraction from water (filters). We extracted DNA from filters with the Puregene kit for tissue (Gentra Systems) with slight modification of the manufacturer's fungal DNA extraction protocol. We added $0.9 \mathrm{ml}$ lysis buffer with proteinase $\mathrm{K}\left(0.1 \mathrm{mg} \mathrm{ml}^{-1}\right)$ to the filter, sealed the capsule and incubated it at $55^{\circ} \mathrm{C}$ for 60 min with continual rotation to bathe the filter in lysis solution. We drained the lysis mix from the filter, and followed the manufacturer's protocol, scaling up solutions by a factor of 3. Extracted DNA was stored at $-20^{\circ} \mathrm{C}$. We extracted field sample DNA as described above and further purified DNA with the abbreviated (to minimize DNA loss) Mobio spin filter cleanup, following the manufacturer's protocol. Next, we used Genereleaser (Bioventures) modified by adding $2 \mu \mathrm{l}$ of DNA extract to $6 \mu \mathrm{l}$ of Genereleaser and heating at $80^{\circ} \mathrm{C}$ for $20 \mathrm{~min}$, followed by centrifuging at $10000 \times \mathrm{g}$ for $5 \mathrm{~s}$. We used $2 \mu \mathrm{l}$ of supernatant in the quantitative PCR, which corresponded to ca. 8 to 80 ng of environmental DNA. DNA was quantified before and after purification using the Quant-it picogreen dsDNA assay kit (Molecular Probes) to assess DNA loss during purification.

DNA extractions from sediment. We extracted DNA from ca. 0.5 to $1 \mathrm{~g}$ of both control sediments (unconsolidated, Bd-negative sediment spiked with $2.55 \times 10^{6}$ zoospores) and sediment samples collected in the field, and extracted DNA with the Ultra clean Soil DNA extraction kit using the manufacturer's alternative protocol to maximize yields (MoBio Laboratories).
Field sampling. We sampled water and sediment from 3 locations at each of 4 sites (Table 1). At each location, we filtered water through Sterivex filters. We secured clean peristaltic pump tubing near the middle of the water column in shallow water $(0.1$ to $0.75 \mathrm{~m}$ deep) in known or likely amphibian habitats. We pumped pond water until filters were nearly clogged and recorded the volume of filtrate produced $(0.05$ to 2.3 l). Filters were pumped dry and stored immediately on dry ice. We scooped sediment samples from the top 5 to $10 \mathrm{~cm}$ of the bed and stored them on dry ice in sterile plastic bags. To avoid cross contamination, all equipment including pump tubing was cleaned with a $10 \%$ bleach solution, followed by rinses with DI (dieonized) water and copious amounts of native water prior to filtration. Blank samples were collected to assess potential contamination by filtering $0.4 \mathrm{l}$ of deionized water through cleaned equipment and a Sterivex filter after visiting several field sites.

Quantitative PCR. We modified 2 published PCR protocols and evaluated them for the detection and quantification of $\mathrm{Bd}$ from laboratory filter tests and from water and sediment samples collected from the field. (1) Quantitative PCR was performed on a MX4000 QPCR system (Stratagene) using a Taqman assay targeting a $97 \mathrm{bp}$ region of the ITS-1 region of the $\mathrm{Bd}$ ribosomal RNA gene locus (bases 14 to 110 of the ITS-1 region), with a 6-FAM labeled TaqMan MGB probe, and cycling parameters: one 9 min step at $95^{\circ} \mathrm{C}$, then 50 cycles of $94^{\circ} \mathrm{C}$ for $30 \mathrm{~s}, 60^{\circ} \mathrm{C}$ for $1 \mathrm{~min}$ (J. S. Wood et al. unpubl.). We constructed a standard curve from a dilution series of Bd zoospore extracts of known concentration, and expressed data as zoospore equivalents. (2) We also modified and tested a protocol from Boyle et al. (2004). Although Boyle et al. (2004) employed a Taqman assay, we used the SYBR green quantitect kit according to manufacturer's instructions (Qiagen) with 1.2 $\mu \mathrm{M}$ each of primers ITS1-3Chytr and 5.8Schytr. These primers target a 146 bp region of the ITS-1 region of the Bd ribosomal operon. PCR was run

Table 1. Field site description. All sites under National Park management. Dates given as mm/dd/yy. TSS: total suspended solids

\begin{tabular}{|c|c|c|c|c|c|c|c|}
\hline Site & $\begin{array}{l}\text { State } \\
\text { (USA) }\end{array}$ & $\begin{array}{l}\text { Sample } \\
\text { date }\end{array}$ & $\begin{array}{l}\text { Water body } \\
\text { type }\end{array}$ & $\begin{array}{l}\text { Amphibians } \\
\text { present }\end{array}$ & $\begin{array}{c}\text { Temperature } \\
\left({ }^{\circ} \mathrm{C}\right)\end{array}$ & $\mathrm{pH}$ & $\begin{array}{c}\text { TSS } \\
\left(\mathrm{mg} \mathrm{l}^{-1}\right)\end{array}$ \\
\hline $\begin{array}{l}\text { Two Medicine } \\
\text { Pond }\end{array}$ & Montana & $7 / 11 / 05$ & Pond/wetland & $\begin{array}{c}\text { Ambystoma macrodactylum, } \\
\text { Bufo boreas, } \\
\text { Rana luteiventris }\end{array}$ & $13-18$ & $6.1-6.5$ & 5.42 \\
\hline Glac 24-25 & Montana & $7 / 12 / 05$ & $\begin{array}{c}\text { Wetland } \\
\text { (recently burned) }\end{array}$ & $\begin{array}{c}\text { Ambystoma macrodactylum, } \\
\text { Bufo boreas, } \\
\text { Rana luteiventris }\end{array}$ & $15.8-16.4$ & $5.7-5.8$ & 8.33 \\
\hline Spruce Lake & Colorado & $7 / 13 / 05$ & Lake & Bufo boreas & $20.2-22.5$ & $5.5-6.0$ & 0.38 \\
\hline Big Meadow & Colorado & $7 / 14 / 05$ & Pond / wetland & Bufo boreas & $18.4-20.3$ & $5.9-6.5$ & 1.12 \\
\hline
\end{tabular}


on an MX3000P instrument (Stratagene). Cycling conditions were as follows: one $15 \mathrm{~min}$ Taq activation step, 40 cycles of $94^{\circ} \mathrm{C}$ for $30 \mathrm{~s}, 57^{\circ} \mathrm{C}$ for $30 \mathrm{~s}$ and $70^{\circ} \mathrm{C}$ for $30 \mathrm{~s}$. At the end of each reaction we performed a melting curve to ensure that no fluorescence used to quantify amplified product was from primer dimer. Initially, we also electrophoresed the products on a $1 \%$ agarose gel to check the fragment size and presence/absence of primer dimer.

We prepared a plasmid containing a Bd amplicon by amplifying strain 197 of Bd with the Boyle primers and then cloning the amplicons into a plasmid with the TopoTA cloning kit (Invitrogen). We quantified plasmid DNA using the Quant-it picogreen dsDNA assay kit (Molecular Probes), and calculated copy number using the formula:

$$
y=[x /(\text { plasmid length } \times 660)] \times 6.022 \times 10^{23}
$$

where $y$ is plasmid DNA (copies $\mu l^{-1}$ ), $x$ is DNA content $\left(\mathrm{g} \mathrm{ll}^{-1}\right)$, and plasmid length is measured in basepairs. To convert copy number to zoospore equivalents, we calculated a conversion factor from a dilution series of known zoospore numbers. Copy number per zoospore was found to be 169, which is within the range of 60 to 220 for rRNA fungal gene locus copy numbers given by Simon et al. (2005). For all qPCRs with both assays, we ran 2 types of negative controls to check for possible contamination during qPCR: (1) a known Bd negative environmental DNA sample, and (2) no template DNA added. We checked for PCR inhibition in 2 ways; first, we assessed DNA purity by comparing results of qPCR before and after Genereleaser treatment. We also used DNA from Desulfovibrio vulnificus, (a bacterium containing the dsrB gene that codes for disulfite reductase) in spiked qPCRs. We spiked qPCRs containing our environmental extracts with this DNA and evaluated inhibition based on gene copy number measured/gene copy number added.

\section{RESULTS}

\section{Bd DNA recovery}

Filtering Bd-spiked liquid through Sterivex capsules resulted in high recovery (mean $\pm \mathrm{SD}=97 \pm 3 \%$ ) when zoospores were spiked into deionized water or PBS, but recovery efficiency was much lower (mean = $37 \pm 15 \%$ ) when zoospores were spiked into pond water (Table 2). Recovery of DNA from sediments was generally low; we achieved a maximum recovery of ca. $10 \%$, but typically recoveries were $<5 \%$ (Table 2 ). DNA purity from sediment tests was high as determined by clarity of the DNA extract and amplification with the quantitative assay, with no evidence of PCR inhibition (SYBR assay with Boyle primers). While recovery was lower than with the water extracts, this would still allow detection of as few as 30 zoospores $\mathrm{g}^{-1}$ sediment.

\section{qPCR performance}

Both assays performed equally well with control filters spiked with Bd (Fig. 1). Quantitative PCRs with the SYBR assay and Boyle primers were reproducible and gave a positive signal from 10 copies, which is equivalent to 0.06 zoospore (see above). The relatively high primer concentration used was necessary for optimal PCR amplification efficiency (>92\%) but did not result in primer dimer (assessed by gel and melting curve analysis). A late PCR cycle (>35 cycles) fluorescence signal increase was sometimes present in $\mathrm{Bd}$ negative environmental DNA controls because of non-specific amplification or background fluorescence. Therefore, positive amplification above the threshold $\left(C_{\mathrm{T}}\right)$ data after 35 cycles was not considered positive. The fluorescence threshold for experiments varied slightly, but was chosen at a point early in each amplification reaction where the standard curve gave the highest $\mathrm{R}^{2}$ value (always $>0.99$ ). The detection limit with the Taqman assay and Wood primers was also 10 copies or 0.06 zoospore equivalents. In this assay, environmental DNA blanks did not give false $C_{\mathrm{T}}$ values; however, $C_{\mathrm{T}}$ values with control zoospore DNA dilutions in late cycles $(>35)$ corresponding to $<10$ target copies were unreliable because of stochastic sampling variability. Therefore, $C_{\mathrm{T}}$ values $>35$ also were scored as negative, or below the limit of detection.

Table 2. Batrachochytrium dendrobatidis. Sterivex filtered water and sediment DNA recoveries. PBS: phosphate buffer solution

\begin{tabular}{|lccr|}
\hline Media & $\begin{array}{c}\text { Recovery } \\
\text { efficiency (\%) }\end{array}$ & $\begin{array}{c}\text { Mean } \\
\text { recovery (\%) }\end{array}$ & SD \\
\hline PBS and & 100 & 96.7 & 3.1 \\
water & 96.2 & & \\
Pondwater & 93.8 & 37.4 & 15.1 \\
& 40.8 & & \\
Pond sediment & 20.9 & 4.3 & 3.0 \\
& 50.6 & & \\
& 3.8 & & \\
& 2.4 & & \\
& 7.9 & & \\
& 1.2 & & \\
& 2.2 & & \\
& 2.7 & & \\
& 4.0 & & \\
& 4.3 & & \\
\end{tabular}




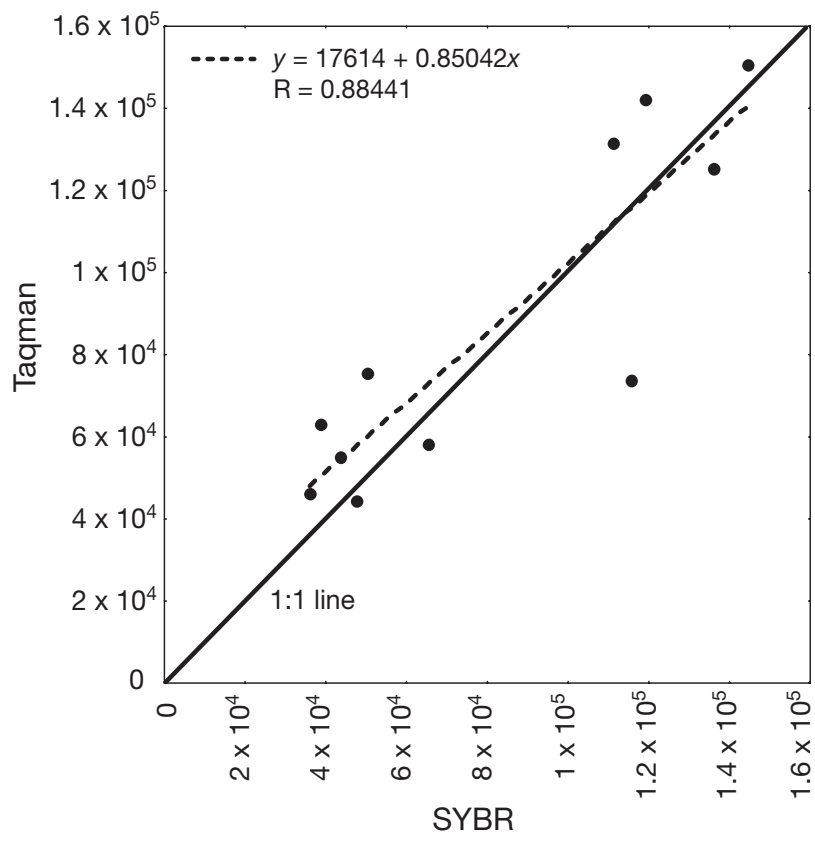

Fig. 1. Batrachochytrium dendrobatidis. Comparison of $\mathrm{Bd}$ qPCR data between Taqman/Wood and SYBR/Boyle assays

\section{Field results}

Field parameters are reported in Table 1. Temperatures at field sites varied between 13 and $23.8^{\circ} \mathrm{C}$, and $\mathrm{pH}$ was between 5.5 and 6.5. Of the 12 samples, 3 tested positive with the Taqman/Wood assay and 6 tested positive with the SYBR/Boyle assay. Two amplicons from the Boyle assay (from samples that did not test positive with the Taqman/Wood assay) were sequenced to confirm that the product was from $\mathrm{Bd}$ (data not shown). When a site tested positive by both methods, the SYBR/Boyle assay estimated greater abundances (Fig. 2). We detected Bd in 3 of the 4 water bodies tested. Results agreed qualitatively with swabs of amphibians collected at the same time (authors' unpubl. data). The range of detected Bd DNA was 19 to 454 zoospore equivalents $\mathrm{l}^{-1}$, the highest at pond 24 25 in Glacier National Park, Montana and the lowest at Spruce Lake in Rocky Mountain National Park, Colorado, both with the SYBR/Boyle assay (Fig. 2). Bd DNA was never detected at all 3 locations sampled in an individual pond site. Bd was not detected in any of the field sediment samples tested. The Genereleaser treated DNAs gave more positive amplifications; none of the DNAs were positive pre- Genereleaser treatment using the Taqman/Wood assay, and 2 were positive with the SYBR assay pre-Genereleaser treatment. The dsrB qPCR showed no evidence of inhibition in either the post-Genereleaser treatment or the sediment samples.

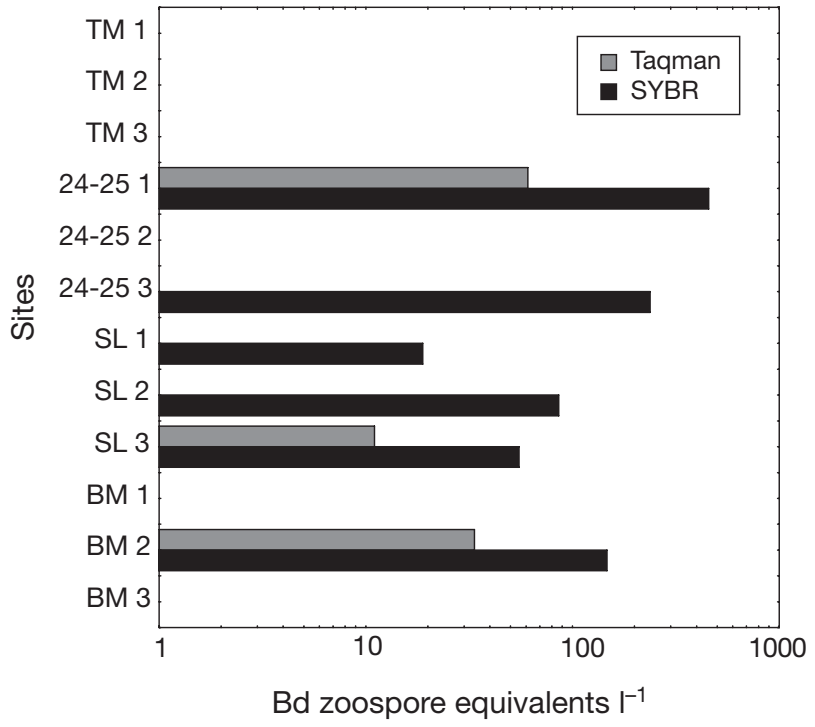

Fig. 2. Batrachochytrium dendrobatidis (Bd). Field qPCR data. Site abbreviations: TM: Two Medicine, Glacier National Park, Montana; 24-25: Glac 24-25, Glacier National Park, Montana; SL: Spruce Lake, Rocky Mountain National Park, Colorado; BM: Big Meadows, Rocky Mountain National Park, Colorado

\section{DISCUSSION}

Selection of DNA extraction and purification strategies is critical to this assay's performance to minimize loss of target DNA while alleviating PCR inhibition. Our 2-step purification resulted in little to no DNA loss as measured by the Quant-it picogreen dsDNA assay, although the Genereleaser treatment dilutes DNA. We emphasize that the levels of $\mathrm{Bd}$ that we report from environmental samples are underestimates, because they were calculated assuming 100\% Bd DNA recovery, yet we know that recoveries from filter extracts are typically less. Therefore, we do not suggest correcting aquatic concentrations based on the laboratoryderived recoveries without first developing locallyspecific calibration curves based on recoveries of spikes with known Bd densities for the water bodies of interest. In addition to the performance of the PCR assay, the detection limit achieved with this method is limited by the volume filtered. In the worst case, we were only able to filter $50 \mathrm{ml}$, which has an effective limit of detection of 30 zoospores $\mathrm{l}^{-1}$. If lower concentrations are suspected, a larger-capacity capsule filter can be used; for example, we filtered up to 641 in separate filter tests of GW $1.0 \mu \mathrm{m}$ filters (Millipore) and successfully quantified Bd DNA in 2 sites in Oregon, USA (data not shown).

Both amplification techniques detected $\mathrm{Bd}$ in environmental samples, but data generated by the 2 quantitative PCR assays differed. In this study, the 
SYBR/Boyle method outperformed the Taqman/Wood method in terms of number of positive detections and abundance of DNA from field samples (Fig. 2). Both the SYBR/Boyle and Taqman/Wood methods have advantages and disadvantages; selection of either can be based on a laboratory's preference or capability. Data generated from qPCR of environmental samples require careful attention to quality control. If using the SYBR/Boyle method, appropriate negative controls are crucial. Melting curves must be performed to ensure that all fluorescence is from amplified Bd DNA and not primer dimer. With these caveats, the SYBR/Boyle method is easy to use and reproducible, with Bd DNA detection of 10 copies, or 0.06 zoospore. It is relatively robust in that the method can tolerate some level of DNA impurity without inhibiting the PCR (as evidenced by the pre-Genereleaser treatment data). The Taqman/Wood method has high specificity and no problems with background fluorescence. It may detect fewer copies, but abundance data in the 10-copy or less range are unreliable because of possible stochastic sampling error. If the Taqman-based assay is to be used, DNA purity is critical; it is therefore always necessary to test qPCRs for evidence of inhibition. Abundances were higher with the SYBR/Boyle method; this may be due to partial PCR inhibition remaining even after cleanup that affected the performance of the Taqman/Wood method.

In summary, the methods developed here allow for the assessment of $\mathrm{Bd}$ distribution and abundance in water and sediment. Although we examined some differences in assay techniques, a thorough direct comparison of $4 \mathrm{Bd}$ PCR assays (Annis PCR, Boyle qPCR, Wood qPCR, SYBR/Boyle qPCR) for sensitivity is in progress (J. S. Wood, Pisces Molecular, pers. comm.). Our field sampling demonstrates that water can now be sampled, with or without concurrent amphibian sampling. This technique will allow researchers to study the implications of Bd's presence in water bodies, to monitor water bodies before reintroduction efforts and to investigate the spread of Bd across the landscape.

Acknowledgements. Thanks to: ARMI Research; D. E. Green and D. Reinitz, USGS Madison Wildlife Health Center; A. Horowitz and K. Elrick, USGS Georgia Water Science Center; M. Adams, C. Pearl, B. McCreary and R. Linden, USGS Forest

Editorial responsibility: Alex Hyatt,

Geelong, Victoria, Australia and Rangeland Ecosystem Science Center; B. Hossack, USGS Northern Rocky Mountain Science Center; E. Muths, USGS Fort Collins Science Center; K. Muths and A. Muths; W. Battaglin and D. Campbell, USGS Colorado Water Science Center; P. Jones, USGS Minnesota Water Science Center; L. Livo, Colorado Division of Wildlife. Three anonymous reviewers provided useful feedback. Source of funding: J.E.L. was supported by NSF Integrated Challenges in Environmental Biology grant DEB \# 0213851. J.D.K., C.W.A. and M.A.V. were supported by the USGS Amphibian Research and Monitoring Initiative. Any use of trade, product, or firm names in this publication is for descriptive purposes only and does not imply endorsement by the US government.

\section{LITERATURE CITED}

Annis SL, Dastoor FP, Ziel H, Daszak P, Longcore JE (2004) A DNA-based assay identifies Batrachochytrium dendrobatidis in amphibians. J Wildl Dis 40:420-428

Australian Government Department of Environment and Heritage (2006) Threat abatement plan for infection of amphibians with chytrid fungus resulting in chytridiomycosis. Canberra, ACT. Available at: www.deh.gov.au/ biodiversity/threatened/publications/tap/chytrid/pubs/ chytrid-report.pdf

Berger L, Speare R, Daszak P, Green DE and 10 others (1998) Chytridiomycosis causes amphibian mortality associated with population declines in the rain forests of Australia and Central America. Proc Natl Acad Sci USA 95: 9031-9036

Boyle DG, Boyle DB, Olsen V, Morgan JAT, Hyatt AD (2004) Rapid quantitative detection of chytridiomycosis (Batrachochytrium dendrobatidis) in amphibian samples using real-time Taqman PCR assay. Dis Aquat Org 60: 141-148

Crawshaw GJ (2000) Diseases and pathology of amphibians and reptiles. In: Sparling DW, Linder G, Bishop CA (eds) Ecotoxicology of Amphibians and Reptiles. SETAC Press, Pensacola, FL, p 199-231

Daszak P, Berger L, Cunningham AA, Hyatt AD, Green DE, Speare R (1999) Emerging infectious diseases and amphibian population declines. Emerg Infect Dis 5: 735-748

Hyatt, AD, Boyle DG, Olsen V, Boyle DB and 11 others (2007) Diagnostic assays and sampling protocols for the detection of Batrachochytrium dendrobatidis. Dis Aquat Org 73: 175-192

Kriger KM, Hero JM, Ashton KJ (2006) Cost efficiency in the detection of chytridiomycosis using PCR assay. Dis Aquat Org 71:149-154

Longcore JE, Pessier AP, Nichols DK (1999) Batrachochytrium dendrobatidis gen. et sp. nov., a chytrid pathogenic to amphibians. Mycologia 91:219-227

Simon D, Moline J, Helms G, Friedl T, Bhattacharya D (2005) Divergent histories of rRNA group I introns in the lichen family Physciaceae. J Mol Evol 60:434-446

Submitted: December 4, 2006; Accepted: May 16, 2007

Proofs received from author(s): July 26, 2007 